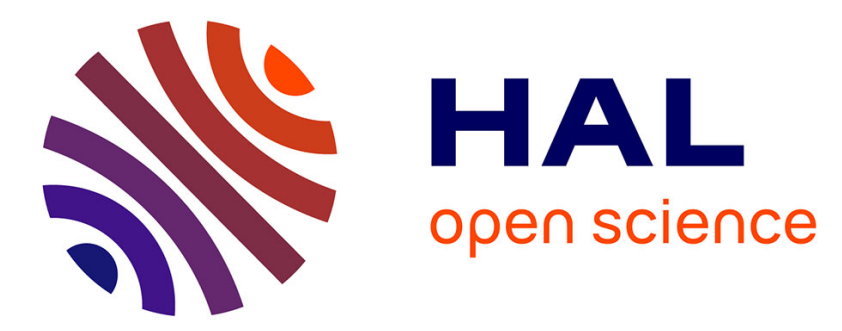

\title{
Significant advances of ethical considerations in biomolecular archaeometry studies of human remains and related materials. The specific case of mummies hair characterization
}

Armelle Charrié-Duhaut, Marie Philipps, Pascale Richardin

\section{To cite this version:}

Armelle Charrié-Duhaut, Marie Philipps, Pascale Richardin. Significant advances of ethical considerations in biomolecular archaeometry studies of human remains and related materials. The specific case of mummies hair characterization. Ethics, Medicine and Public Health, 2021, 17, pp.100658. 10.1016/j.jemep.2021.100658 . hal-03217589

\author{
HAL Id: hal-03217589 \\ https://hal.science/hal-03217589
}

Submitted on 11 May 2021

HAL is a multi-disciplinary open access archive for the deposit and dissemination of scientific research documents, whether they are published or not. The documents may come from teaching and research institutions in France or abroad, or from public or private research centers.
L'archive ouverte pluridisciplinaire HAL, est destinée au dépôt et à la diffusion de documents scientifiques de niveau recherche, publiés ou non, émanant des établissements d'enseignement et de recherche français ou étrangers, des laboratoires publics ou privés. 


\title{
Armelle Charrié-Duhaut, Marie Philipps, Pascale Richardin
}

\author{
Significant advances of ethical considerations in biomolecular archaeometry \\ studies of human remains and related materials. The specific case of \\ mummies hair characterization.
}

\begin{abstract}
Summary
Biomolecular archaeometry is an interdisciplinary discipline integrating humanities and hard sciences to support better knowledge of past societies. Some human remains, such as hair, are among the archaeomaterials likely to be studied by these invasive techniques which provide access to molecular data thanks to mass spectrometry among others. A necessary collective reflection is already underway to best integrate ethical considerations into the research programs. It includes various parameters such as compliance with the legislation in force, definition of a historical questioning before the studies, relevance and excellence of the analyses, adaptability of analytical protocols to the context of heritage materials, implementation of new operating chains from the sampling of the object to its final storage, conservation of the remains.
\end{abstract}

\section{KEYWORDS}

Biomolecular archaeometry; Ethics; mummy hair; Mass spectrometry; Analysis; Preservation 


\section{Introduction}

Biomolecular archaeometry is a scientific field that has experienced a real growth in recent years due to the awareness of the exceptional informational potential of organic and biological remains, so far underestimated. At the interface between the hard sciences and the humanities, it offers a new perspective on past societies, by carrying out chemical and physicochemical analyses on archaeomaterials through dedicated technological developments. What are archaeomaterials? This corresponds to any organic or biological material, thus perishable, present in an archaeological or museal context in association or not with other components (ceramics, metals, glass). Human remains and related biological products are therefore included, such as hair. It is clear that ethics is an area that is more addressed by the various actors of the humanities. However, it does not prevent that these are considerations that are now taken into account in biomolecular archaeometry with a sensitivity that may be different but with common objectives. This article is related to the international symposium "Anthropo-responsabilité" held on January 28 and 29, 2021 at the "Musée du quai Branly Jacques Chirac" (Paris).

\section{The basics of biomolecular archaeometry}

The aim in biomolecular archaeometry is to characterize at the molecular level archaeomaterials, one of the key techniques being mass spectrometry. This characterization is based on the structural identification of biomarkers, which are characteristic molecules of a natural substance or a transformation process. Each substance can thus be characterized by its molecular fingerprint, i.e. by the qualitative and quantitative distribution of its biomarkers identified by mass spectrometry [1] Two sets of biomarkers whose studies require different analytical protocols are distinguished. The first category includes molecules of low molecular weight such as lipids allowing the identification of fatty substances (plant oils, animal fats) or terpenes in plant products (resins, tars). The second set corresponds to proteins such as collagen (already used for leather analysis) and keratins, which have been the subject of pioneering studies in the laboratory LSMIS of Strasbourg for the characterization of hair, fur, felt and textile. We will not speak here of DNA, a scientific field which has its own protocols and ethical criteria. Concerning mummy's hair, a research axis which will be specifically developed in this article, an interest is on both the capillary fiber and any external contributions (pigment, coating).

Biomolecular archaeometry develops new concepts for a better knowledge of past societies. It provides answers and new perspectives for humanities' crucial issues. These lasts can be divided into four axes: identification and characterization of the remains (what are they made of?), geographical origin (where do they come from?), information on past technologies, know-how, uses and customs 
(how were they processed or manufactured?), assessment of the degree of preservation and studies of alteration processes (are they degraded? how can they be better preserved and restored?).

\section{Ethical considerations regarding archaeomaterials}

In recent decades, and in our view, more and more ethical considerations have been brought to archaeomaterials by specialists in chemical and physico-chemical analyses. From a very practical point of view, but which has become unavoidable, they ensure that they have all the legal authorizations to collect, to be in possession of the collected sample and, depending on the case, to destroy it by analysis. They must also be careful not to accumulate samples unnecessarily and to share them when possible.

Whether it is human remains or organic traces left by human activity (adhesive on a flint, sword scabbard, textile cover in a burial, offerings, jewel, cosmetic or culinary residue, etc.), the same consideration should be given to archaeomaterials. They are all part of heritage and are therefore precious and rare. These are clues left by past societies so they are all related to human beings. Allowing analyses to document the material history of ancient artefacts, ecofacts and individuals by deciphering hidden messages can also be considered a form of respect. Furthermore, the knowledge gained from these studies goes beyond historical and archaeological information alone. Indeed, from a fundamental point of view, biomolecular archaeometry analyses carried out on ancient samples allow to develop protocols adapted to extreme conditions (see next point) and to study the natural ageing and modifications at the molecular level of various structures such as proteins, which may have implications for our current societies. Regarding these rare and precious heritage materials, there is therefore a balance to be found between our duty of preservation and our thirst for knowledge.

In our opinion, this duty of preservation is part of the ethical considerations and the respect to be had in relation to these remains. It obviously involves limiting as much as possible invasive sampling and manipulations which are potential sources of contamination and physical damage. It also includes identification of the molecular-scale alteration processes that appear as modifications of the original molecular fingerprints. These changes may be due to anthropogenic action (heating, cremation, dehydration) or linked to natural ageing (oxidation, biodegradation). New molecular tools can be put in place to assess the degree of preservation and to better preserve and restore remains.

\section{Specifically dedicated protocols in biomolecular archaeometry}

Excellence in the field of expertise is also an integral part of ethics, a consideration required in many fields in both the hard sciences and humanities. Mass spectrometry is a technique with various 
applications in the food industry, pharmacy, environment, geochemistry, etc. However, its use for the analysis of ancient remains should be the domain of specialists of this type of material, given the particular issues and context. Just as archaeologists or curators are not just samples suppliers, archaeometers are not just an analysis provider. They bring expertise and must be able to dialogue with the specialists from other disciplines. Each sample is different and has an often unknown history from its birth / production to its final storage, through its burial and its discovery. In order to achieve the desired excellence, it is therefore necessary to be able to adapt analysis protocols while guaranteeing the reliability of the biomolecular results. The specialists in biomolecular studies should not be locked into strict procedures but on the contrary keep flexibility to adapt to archaeomaterials and historical questioning. The analytical challenge is still important because of various essential parameters: complexity of molecular fingerprints, potentially composite materials, small quantities available, alteration. Specifically dedicated protocols are to be implemented for addressing this issue.

Moreover, the debate on the use of invasive versus non-invasive methods is still open [2]. Some information can only be obtained after sampling and analysis by destructive techniques such as radiocarbon dating and biomolecular archaeometry. Again, a balance must be achieved between the desire to acquire new knowledge and the preservation of the integrity of the archaeomaterials, including human remains. It should be noted that particular care is taken to minimise the amounts of samples to be committed, which requires particular methodological developments. This was done for radiocarbon dating [3] and proteomic analysis of mummy's hair [4, 5]. Thus the biomolecular study of the proteins constituting current capillary fibers is generally carried out on about $10 \mathrm{~g}$ [6]. In the LSMIS laboratory, a protocol using only $500 \mu \mathrm{g}$ of hair while maintaining the reliability of the results was developed.

\section{Interdisciplinarity and ethics}

At present, the approach to study organic and anthropo-biological remains is highly inter- and multidisciplinary. New questions arise: respect due to human remains, choice and priority of analyses to be perform, budgets to be foreseen, preservation/restoration/exhibition of remains, etc. To answer this, an optimization of the operating chain from the excavation site to the final storage places is to be carried out, taking into account together the requirements related to the historical questions, the imperatives linked to the materials and the interventions crossover of the various specialists [7]. The reliability of chemical and physico-chemical results, among other data, will strongly depend on the archaeological reflection initiated upstream, even before the sampling. Specialists responsible for analyses, archaeologists, curators, restorers, collection managers, members of the "Directions régionales des affaires culturelles" (DRAC) and the regional 
archaeological services (SRA) will act to define a specific issue related to the object. The planning of the stages is the main thrust of the research and preservation process and this will begin from the inscription in the specifications and up to the curative conservation and the archaeological restitution. A collective reflection of an interdisciplinary local Alsatian working group (coordinators: H. Barrand-Emam, A. Charrié-Duhaut, F. Médard, C. Proust) in close collaboration with the SRA Alsace was undertaken to optimize the conduct of studies throughout the operating chain of archaeology. A brochure devoted to the sampling, storage and physico-chemical study of archaeomaterials was recently published [8].

\section{The "mummy hair" project at LSMIS (UMR7140, Strasbourg): what specific ethical issues?}

The most frequently studied anthropo-biological remains are bones and teeth, with two types of analysis particularly developed: genetic analysis and radiocarbon dating. Hair seem less important than other human remains yet they prove equally informative [9]. Moreover, it allows less invasive sampling without compromising the integrity of the remains: it is easier to take hair than a tooth or a piece of bone. Very robust material that can be preserved for centuries, hair is a powerful bioindicator [10] as it incorporates substances carried by blood such as certain toxic components, for example arsenic in the hair of South American mummies [11]. Biomolecular analyzes of hair can provide a wide range of information on the individual's environment, diet, habits and customs as well as on funeral rites [12]. This research axis is one of the priority axes in the mass spectrometry laboratory LSMIS (UMR 7140, Strasbourg), pioneer in this type of study. However, it is amazing that a material as mundane as human hair that people cut without any ulterior motive in our lifetime can take on so much importance when it belongs to a person from a past society.

In museal context, hair preservation is a problem. As an example, it was observed during the Antinoé project (multidisciplinary scientific study of a large corpus of Coptic mummies from Egypt) that hair of some mummies were in perfect state while others are weakened or in powder form and this without any apparent reason [13]. Some hair from the major exhibitions in the 19th century (collection of the "Musée des Confluences", Lyon) was stored with naphthalene, others treated with alcohol, but what about the degree of preservation and the alteration processes? It is important to realize that even if ancient hair appears macroscopically and even microscopically in relatively good condition, its biomolecular structure can be weakened, the processes of alteration still in action which may lead to a point of no return and to the destruction of the capillary fibers. It is therefore ethically necessary to implement molecular tools to assess the degree of preservation of the hair fiber in order to maintain the integrity of human remains in the long term, to ensure the reliability of the results obtained, to be able to restore safely and to possibly expose. 
The new proteomic protocol adapted for the analysis of 500 $\mu$ g of ancient hair [5] was applied on a hair sample from an Andean mummy, conserved the National Museum of Natural History (Musée de l'Homme) in Paris (France) (Fig 1). This mummy was the subject of a study for its restoration by P. Carminati in 2010 [14] and according to the radiocarbon dating belongs to the Late Intermediate period (900 - 1450 AD) [3]. In this study, dry and fragile hair with significant damage caused by keratotophagus insects and a tendency to disengage from the body is mentioned. The biomolecular tools set up to assess the degree of preservation will be presented thanks to the proteomics analysis of the hair of this mummy. Briefly, hair is mainly composed of 18 fibrous a-helical proteins called keratins divided into two groups: acidic type I and basic type II. These keratins combine to form tetrameric cylinder-like filaments which assemble into macrofibrils. To ensure the cohesion of the latter, a matrix composed of other proteins very rich in sulfur, the Keratin Associated Proteins (KAPs), is present. The proteomic analysis protocol according to a "bottom-up" strategy consists in using a digestion enzyme which will cut the chains of amino acids constituting the proteins in very precise locations to form peptides. These peptides are then characterized by mass spectrometry and after bioinformatic processing, it is possible to identify the proteins present as well as the modifications that appeared on their structure. The precise structural composition of mummy's hair is compared with that of several actual hairs including Chilean hair. Four parameters are indicators of a molecular modification of the hair structure, resulting in a significant weakening of the fiber. The first is directly observable during the protein extraction step of the proteomic analysis protocol. While the current hair fibers are still clearly visible in the extraction medium, the ancient hair has disappeared and appears to have been fully solubilized. The second parameter is observed on the MALDI-MS (MS: mass spectrometry) spectra of hair digests that show the mass range covered by the peptides of the modern and ancient samples. Mummy hair peptides are less abundant and spread over a narrower mass range than those of current hair, indication of a potential fragmentation of protein assemblies. These two indications show a breakdown of the hair fiber. The third indicator of a molecular change is given by the number of proteins identified. While this number is the same for keratins in modern and ancient hair, it is not the case for KAPs (Fig 2). Indeed, a very strong decrease is observed in mummy hair compared to modern reference hair reflecting their alteration. As a reminder, the role of these KAPs is to ensure cohesion of the fiber which is therefore less in ancient hair. The last parameter is the most precise at the structural level since it will be interested in changes in the amino acid structure, accessible after analysis by nanoLC-MS/MS. Several modifications not induced by the protocol will be taken into account: oxidation, desamidation, methylation, acetylation, glutamic acid cycling. The percentage of modified peptides can thus be evaluated. It is significantly higher (between 60 and 85\%) in mummy hair compared to reference hair (between 15 and 50\%) (Fig 3). 
In addition, a clear separation of the two types of keratins appears in ancient hair. The structure of type II keratins has fewer modified peptides than those of type I keratins. The latter, located in the center of the hair, would therefore be more sensitive to degradation. The same observations were made by selecting a specific modification such as the oxidation of cysteines and the desamidation of asparagines and glutamines, a modification considered to be a molecular biological clock [15]. The rate of individual modification is significantly higher in mummy hair, especially for type I keratins. Several biomolecular tools therefore make it possible to assess the degree of preservation and to follow the evolution of hair degradation.

\section{Conclusion}

During the last decades, the interdisciplinarity of archaeological studies has led to an evolution of the approaches. The notions of ethics have become full components in the new research projects submitted. It is no longer enough to juxtapose results from different scientific fields ant it requires a collective reflection. It is therefore necessary to rethink the operating chains to guarantee the respect of archaeomaterials, especially of human remains. Balances between knowledge to be discovered by analysis of the remains and their preservation must be found. Preservation means not only avoiding the taking of multiple samples which threatens the integrity of the vestige, but also preventing it from further degradation. This last point is important in biomolecular archaeometry. Having the ability to define a degree of preservation at the molecular level and to unravel the parameters that induce alteration are important factors in planning appropriate analytical and restoration strategies as well as suitable storage conditions. All these ethical considerations are to be considered as positive advances and not as blocking points for analyzes. 


\section{Acknowledgments}

The authors thank the organizing committee of the international symposium "anthroporesponsabilité" (28 and 29 January 2021, musée du quai Branly Jacques Chirac, Paris) for allowing them to present their work and share their point of view. The authors also thank E. Leize-Wagner director of the LSMIS, JL Schmitt from the ISIS analysis platform and the team from StrasbourgEsplanade proteomics facility for technical support in mass spectrometry.

\section{Disclosure of interest}

The authors declare that they have no competing interest.

\section{References}

[1] Charrié-Duhaut A, Burger P, Maurer J, Connan J, Albrecht P. Molecular and isotopic archaeology: Top grade tools to investigate organic archaeological materials. Comptes Rendus Chimie 2009; 12, 1140-1153. https://doi.org/10.1016/j.crci.2009.01.001

[2] Moissidou D, Day J, Shin D H, Bianucci R. Invasive versus Non Invasive Methods Applied to Mummy Research: Will This Controversy Ever Be Solved? BioMed Research International 2015; 192829. https://doi.org/10.1155/2015/192829

[3] Richardin P, Gandolfo N, Carminati P, Walter P. A new protocol for radiocarbon dating of hair and keratin type samples-application to an Andean mummy from the National Museum of Natural History in Paris. Archaeol Anthropol Sci 2011; 3, 379-384. https://doi.org/10.1007/s12520-011-0070-

[4] Fresnais M, Richardin P, Gimat A, Sepúlveda M, Leize-Wagner E, Charrié A. Recent advances in the characterization of hair of mummies from the Chilean Andean coast. Forensic Science International 2015, 249, 25-34. https://doi.org/10.1016/j.forsciint.2015.01.005

[5] Fresnais M, Richardin P, Sepúlveda M, Leize-Wagner E, Charrié-Duhaut A. Omics for Precious Rare Biosamples: Characterization of Ancient Human Hair by a Proteomic Approach. OMICS: A Journal of Integrative Biology 2017; 361-370. https://doi.org/10.1089/omi.2017.0067

[6] Lee YJ, Rice RH, Lee YM. Proteome analysis of human hair shaft: from protein identification to posttranslational modification. Molecular and cellular proteomics 2006; 5, 789-800. https://doi.org/ 10.1074/mcp.M500278-MCP200 
[7] Charrié-Duhaut A, Médard F, Proust C, Barrand-Emam H. Les restes organiques minéralisés : un nouveau champ d'investigation en contexte funéraire. Exemple de la nécropole de Merxheim « Obere Reben » (Haut-Rhin). In : Carpentier C, Arbogast RM, Kuchler P, editors. Bioarchéologie : minimums méthodologiques, référentiels communs et nouvelles approches : actes du 4e séminaire scientifique et technique de l'Inrap, 28-29 nov. 2019, Sélestat ; 2020. https://doi.org/10.34692/ftgfzd86

[8] Charrié-Duhaut A., Médard F., Mazuy A. Bio-archéologie : sensibilisation au prélèvement, au stockage, à l'étude physico-chimique de macro/micro-résidus organiques, 2020.

https://doi.org/10.5281/zenodo.4008867

[9] Wilson AS. Hair as a bioresource in archaeological study. In: Tobin DJ, editor. Hair in toxicology: an important bio-monitor, The Royal Society of Chemistry, RCS Publishing, Cambridge, 2005; Part IV, p. 321-344.

[10] Tobin DJ. Hair in toxicology. The Royal Society of Chemistry, RCS Publishing, Cambridge, 2005.

[11] Kakoulli I, Prikhodko SV, Fischer C, Cilluffo M, Uribe M, Bechtel HA, Fakra SC, Marcus MA. Distribution and Chemical Speciation of Arsenic in Ancient Human Hair Using Synchrotron Radiation. Analytical Chemistry 2014; 86(1), 521-526. https://doi.org/10.1021/ac4024439

[12] Diaz-Zorita M, Drucker D, Richardin P, Silva- Pinto V, Sepúlveda M, Bocherens H. Marine food consumption in coast northern Chilean (Atacama Desert) population during the Formative Period: Implication of isotopic evidence (C, N, S) for Neolithic process in south central Andes. Journal of Archaeological Sciences 2016; 6, 768-776. https://doi.org/10.1016/j.jasrep.2016.01.026.

[13] Vargiolu R, Pailler-Mattei C, Coudert M, Lintz Y, Zahouani H. Hair surface and mechanical properties of Copt mummies from Antinopolis. Journal of Archaeological Science 2013; 40(10), 36863692. https://doi.org/10.1016/j.jas.2013.04.007

[14] Carminati P. Les momies du Muséum national d'Histoire naturelle : du cabinet anthropologique au musée de I'Homme. La Lettre de I'OCIM [Online] $2011 ; 137$. https://doi.org/10.4000/ocim.966

[15] Perez Hurtado P, O’Connor PB. Deamidation of Collagen. Analytical Chemistry 2012; 84(6), 30173025. https://doi.org/10.1021/ac202980z

\begin{tabular}{|l|}
\hline Mis en forme : Anglais (Royaume-Uni) \\
\hline Mis en forme : Anglais (Royaume-Uni) \\
\hline Code de champ modifié \\
\hline Code de champ modifié \\
\hline Mis en forme : Anglais (Royaume-Uni) \\
\hline Mis en forme : Anglais (Royaume-Uni) \\
\hline Code de champ modifié \\
\hline Mis en forme : Anglais (Royaume-Uni) \\
\hline Code de champ modifié \\
\hline
\end{tabular}

